\title{
Regional Integration and Income Inequality in ECOWAS Zone
}

\author{
Muriel Eyram Silo Ametoglo \\ School of Economics and Trade, Hunan University, Changsha 410079, China \\ Ping Guo \\ School of Economics and Trade, Hunan University, Changsha 410079, China \\ Kwami Ossadzifo Wonyra \\ LAREA, Université de Kara, BP 43, Togo
}

\begin{abstract}
This paper investigates the relationship between regional integration and inequality for the 15 states in the Economic Community of West African States (ECOWAS) over the period of 2004 2013. Our results suggest that political integration reduces income inequality, while economic integration increases the income gap in ECOWAS zones.
\end{abstract}

JEL Classification: F14, F15, D31, O15

Keywords: Regional integration, Income inequality, Economic integration, Political integration

\footnotetext{
* Corresponding Author: Muriel E. S. AMETOGLO; School of Economics and Trade, Hunan University, Changsha 410079, China, E-mail: murielametoglo@hnu.edu.cn

Co-Authors: Ping Guo; School of Economics and Trade, Hunan University, Changsha 410079, China; E-mail: gping1963@163.com Kwami Ossadzifo WONYRA; Laboratoire de Recherche en Economie Appliquée (LAREA), Faculté des Sciences Economiques et de Gestion FASEG, Université de Kara, BP 43, Togo; E-mail : wonyra.ossa@gmail.com
} 


\section{Introduction}

In recent years, considerable attention has been paid to the relationship between globalization and inequality. Beckfield (2006) states that regional integration is more powerful than globalization when it comes to income inequality. In fact, much of what is designated as globalization in the literature might be considered regionalization (Fligstein 2001).

Regional integration is commonly presented in twofold dimension: political and economic integration (Fligstein and Stone Sweet 2002, Beckfield 2006). Political integration could affects income inequality by allocating political competencies to regional institutions. Three reasons explain this mechanism. First, political integration affects inequality through national fiscal policies. Higher levels of political integration are associated with lower levels of public spending in general and social spending in particular (Busemeyer and Tober 2015). Second, political integration transfers political responsibility from the national government to the regional union (Beckfield 2006). Third, political integration limits the autonomy of national economies, which can lead to sovereignty concerns (Beckfield 2006).

Economic integration also can affect income inequality. For instance, in international trade, the Heckscher-Ohlin-Samuelson theorem specifies that when poor countries engage in more global trade, they produce goods in which they have a comparative advantage. This likely increases the demand for low-skilled labor and the wages of low-skilled workers. As a result, inequality may decline. The reverse situation would happen in rich countries: as they export more high-skilled goods, inequality may rise.

The aim of this study is to analyze the link between regional integration and income inequality, with a special focus on ECOWAS zones. Empirical studies on the relationship between regional integration and income inequality are scant, and most of them focus on European integration. To shift the attention from European to African regional integration, we examined all fifteen ECOWAS countries.

Regarding economic integration, it is still unclear whether intra-regional trade has enhanced social development or led to Africa's widespread inequality and poverty. Because it fosters trade, intra-regional trade can promote inclusive growth and reduce income inequality. Although ECOWAS experienced significant growth in global trade (between 1980 and 2014, total 
merchandise imported by ECOWAS quadrupled), the intra-regional exports remained relatively small: In 2015, the share of intra-ECOWAS exports was about 10 percent of total exports, lower than the 19 percent for MERCOSUR, 24 percent for ASEAN, and 73 percent for OECD countries (UNCTAD 2017). Even within Sub-Sahara Africa, with the exception of ECCAS, intraECOWAS exports were smaller than for other groups. On the other hand, ECOWAS had the second highest intra-regional share of imports. Although intra-ECOWAS trade remained relatively low, intra-regional trade was diversified (UNCTAD 2017). We find that intra-regional export ratio affected income inequality positively, which supports the diversion effect of intraregional trade on welfare in ECOWAS (Viner 1950).

We include two aspects of regional integration: political and economic integration. To measure political integration, we follow Beckfield (2006, 2009) which defines political integration as the number of cases referred from national courts to regional legal institutes. Economic integration is evaluated as the percentage of a country's total exports going to each regional zone member country (Frankel 1997). We use a panel estimation method with a dynamic specification taking into account the path-dependent nature of the income inequality's distributional pattern and the Least Squares Dummy Variable Corrected (LSDVC) method to address plausible issues of endogeneity.

Some key findings emerge. First, political integration has a strong, statistically significant impact on reducing income inequality in ECOWAS. Second, economic integration, measured by intra-regional export ratio or the share of total intra-regional goods trade (as a percentage of total ECOWAS trade), strongly increases income inequality. Third, the effect of share on total intra-regional goods trade (as a percentage of total ECOWAS trade) is stronger than the individual intra-regional export ratio (as a percentage of a country's total exports) in explaining the rise in the Gini coefficient. Fourth, the past value of the Gini coefficient accounts for the path-dependent and viscous nature of inequality. Fifth, Foreign Direct Investment (FDI) significantly reduces income inequality, while unemployment naturally has the opposite effect.

The remainder of the paper is organized as follows. The next section reviews the extant literature. Section 3 presents the empirical model, the data, and the methodology. The empirical results and robustness are discussed in Section 4. Section 5 concludes the paper. 


\section{Literature}

There are several theoretical models on how integration affects income distribution across regions. According to the "race to the bottom" approach, one would expect regionalization to aggravate states' economic burdens. This approach advocates that as regional integration rises, especially in terms of trade and capital openness, social spending is likely to decrease. Regional integration could lead to cuts in social spending because countries within regional organizations strive to attract or to keep capital.

Viner (1950) is among the first to consider welfare in a theory of regional trade in general and specifically into the theory of customs unions. $\mathrm{He}$ discussed integration's gains, and found two possible effects of economic integration: trade creation and trade diversion. Trade creation occurs when two or more countries enter into a trade agreement, and trade shifts from a high-cost supplier member country to a low-cost supplier member country. Trade diversion occurs when imports shift from a low-cost supplier of a nonmember country of the union (a third country) to a high-cost supplier member country. This may take place when a common tariff protects a high-cost supplier member inside the union. Viner stated that trade creation raises a home country's welfare, while trade diversion lowers it.

Developing Viner's theory, Johnson (1975) argues that trade diversion may increase welfare if both production and substitution effects are taken into account. The welfare losses resulting from trade diversion can be offset by welfare gains obtained from the elimination of import tariffs.

New economic geography theory argues that regional integration could increase income inequality. By promoting trade and factor mobility, deeper economic integration creates new opportunities for economies of scale, activity specialization, and economic agglomeration. This could, though, generate regional disparities in growth, factor accumulation, and income disparities (Brühlart and Tortensson 1996, Fujita et al. 1999, Puga 1999, Martin 2002). Since economic integration generates a larger labor market and increases wage competition between workers (Alderson and Nielsen 2002, Western 1997), economic integration is likely to raise income inequality because workers are exposed to competition in regional labor markets (Beckfield 2006).

Several empirical studies using the European experience point out that 
regional integration coincides with a substantial decrease in income inequality between countries (Leonardi 1995, Armstrong 1995). However, other papers find a pattern of divergence (Slaughter 2001, Arestis and Paliginis 1995). Western (1997) confirms that economic integration tends to create a larger labor market and increases wage competition between workers. With labor exposed to competition from beyond national boundaries, its bargaining power weakens, either through unions losing influence or by other means. In this case, further integration is expected to increase inequality (Alderson and Nielsen 2002). Beckfield (2006) uses two measures of regional integration, that is, political and economic integration, to investigate their relationship to income inequality for 12 Western European countries between 1973 and 1997. With a random and a fixed-effect analysis, he discovered that economic and political integration increase income inequality. Busemeyer and Tober (2015) measures the extent of European integration relying on a new dataset covering 14 European Union member states over the period of 1999 2010 and finds an evidence for a positive and statistically significant relationship between regional political integration and inequality. However, economic integration exhibits no systematic association with the Gini coefficient.

Ezaki and Nguyen (2008) studies the effects of regional economic integration on growth, income distribution, and poverty in four East Asian countries: China, Indonesia, Thailand, and Vietnam. The study develops a global Computable General Equilibrium (CGE) model based on the data and structure of the Global Trade Analysis Project (GTAP) model. They show that East Asian Free Trade Agreements (EAFTA) generally has positive effect on growth leading to poverty reduction. Ametoglo and Guo (2016) carries out a panel analysis to examine the effect of regional economic integration on income inequality in the Andean Community of Nations (CAN) and shows that regional trade fueled a decline of income inequality in the region.

Hérault (2005) analyzes the effects of trade liberalization on poverty and inequality in South Africa using a macro-oriented CGE model and a microsimulation (MS) model. The study detects that trade liberalization leads to poverty reduction for white South Africans, who emerged as the main winners from the policy. Osakwe (2015) argues that while regionalism can reduce poverty in Africa, it would require a shift from trade reform-oriented integration to a transformative regionalism which is an integration approach that promotes and ensures progress in building productive capacities and 
achieving structural transformation for sustained developement. Kweka and Mboya (2004), in a case study of Tanzania, finds that regional integration within SADC and EAC improves trade. It also notes that regional trade had a higher anti-poverty impact because it directly provided the poor with employment and sales opportunities.

\section{Methodology}

\section{A. Data}

\section{The dependent variable}

The dependent variable is the Gini coefficient, a widely used measure of inequality that varies from 0 to 1 . We collect the data from the World Development Indicators (WDI) from 2004 to 2013 at the World Bank. We assume a five-year invariance of the Gini coefficient in each country in dealing with the missing data.

\section{Regional integration variables}

Following Beckfield (2006, 2009), political integration is measured as the number of cases referred from national courts to the ECOWAS Community Court of Justice under Articles 6 and 15 of the Revised Treaty of the Community ECOWAS. The court is mandated to observe the law, the principles of equity, and the provisions of the Revised Treaty. ${ }^{1}$ The more cases a country refers to the ECOWAS Court of Justice, whether defendant or plaintiff, the more integrated the union becomes, because each member country agrees to abide by Community law (Burley and Mattli 1993). This implies a deeper integration among 15 member countries. The data was obtained from the ECOWAS Community Court of Justice's list of decided cases.

We measure trade integration as a country's total exports to ECOWAS countries or the intra-regional export ratio. Intra-regional trade share data are from the UNCTAD statistic database. 


\section{Control variables}

Several variables may influence income inequality. The choice of control variables for entrepreneurship follows the literature, and all control variables were accessed from the WDI, released by the World Bank.

We add Gross Domestic Product (GDP) per capita as a measure of economic development. Kuznets (1955) stipulates that income inequality increases in the early stage of economic growth. By contrast, when countries reach the threshold, income inequality decreases.It depicts the well-known inverted U-shaped relationship between income inequality and economic growth. Anyanwu, et al. (2016) finds evidence of a dynamic, non-monotonic, inverted, U-shaped curve between economic growth and income inequality in West Africa. However, Ravallion (1995), Fishlow (1995), and Deininger and Squire (1997) argue that there is no significant relationship between them.

FDI refers to total direct foreign investment as a share of GDP. It is the net investment inflows to maintain management control of an enterprise operating in a foreign country. Several empirical studies associate FDI with greater inequality (Aitken et al. 1996, Feenstra and Hanson 1997, Hanson 2003). Hyungsun and Miguel (2017) examines the effect of FDI inflows and FDI stock on income distribution for seven Southeast Asian countries from 1990 to 2013 and finds higher FDI inflows exacerbate income inequality.

Another control variable is remittances as a percentage of GDP. Remittances include personal transfers and compensation of employees, either in cash or in kind. In Latin American and Caribbean countries, remittances appear to boost growth and ease inequality (Acosta et al. 2007). A 2006 household survey in Mali (Gubert et al. 2009) indicates that remittances diminish income inequality by about five percent. Other studies, though, reveal that migration and remittances increase inequality in Ghana (Adams et al. 2008), rural Egypt (Adams 1991) and Sub-Saharan and North Africa (Anyanwu 2011).

High unemployment leads to more poverty and inequality, resulting in greater demands for welfare programs. Monnin (2014), in a study of developed countries, finds that unemployment increases income inequality.

We introduce the Country Policy and Institutional Assessment (CPIA) index as a corruption variable. The CPIA illustrates transparency, accountability, and corruption in the public sector. Higher index values, 
between 1 and 6, mean more corruption. Tebaldi and Mohan (2010) observes that an economy with robust corruption control, supported by an efficient government, produces favorable conditions to promote growth and alleviate conflicts in income distribution. Moreover, a wide range of papers present evidences that corruption aggravates income inequality (Gupta et al. 1998, Gyimah-Brempong 2002).

Inflation rate measured by the Consumer Price Index (CPI) is expected to raise the Gini coefficient. Easterly and Fischer (2001) reports that higher inflation rate reduces the well-being of the poor. Several papers also claim that high inflation rate could raise income inequality (De Melo et al. 2006, Albanesi 2007), while low inflation rate could reduce it (Bulir 1998, Lopez 2004). Inflation rate seems to be the strongest factor increasing income inequality in Africa (Anyanwu 2011).

We include the rate of population growth in our model. Population growth is assumed to worsen income inequality in developing countries. Chenery (1976) shows that poor families tend to have more children than rich ones. Consequently, each of them gets a lesser share in poor households. Claus et al. (2012) also theorizes that a rise in population growth would raise labor supply, which lowers wages ending up with increasing income inequality.

We include the natural resources quantified by the sum of rents for oil, natural gas, coal, minerals, and forests. Ali and Sami (2016) point out the forest and oil rents have contributed to the reduction of inequality in 22 countries of the Middle East and North Africa by using panel data from 1963 to 2012. Torvik (2002) argues that natural resource rents deflect entrepreneurial talent from productive activities to low-productive rentseeking activities.

\section{B. Model}

We employ a modified model of that presented in Beckfield $(2006,2009)$ and test the following equation:

$$
\begin{gathered}
\text { GINI }_{i, t}=\alpha_{0}+\alpha_{1} \text { GINI }_{i, t-1}+\alpha_{2} \text { POLI }_{i, t}+\alpha_{3} \text { TRADE }_{i, t} \\
+\sum_{j} \delta_{j} X_{i j t}+\theta_{i}+\mu_{i, t}
\end{gathered}
$$

where GINI is the inequality measure, POLI is the number of cases referred to 
the ECOWAS Community Court of Justice, and TRADE represents the trade integration score measured as an country's intra-regional export ratio. $X$ is a vector for control variables. $\theta_{i}$ is an unobserved individual effect and $\mu_{i t}$ is unobserved white noise disturbance. All variables are in logarithm except for the inflation rate, the corruption index, and political integration.

We use a dynamic specification to estimate the impact of regional integration on income inequality over the period of 2004 2013. Dynamic specification is necessary in that income inequality can be captured as an autoregressive process, where the degree of past inequality affects present inequality. We introduce lagged values of inequality and test whether they are associated with higher, contemporaneous levels of GINI. As indicated by Reuveny and Lee (2003), the inclusion of lagged values of inequality helps to control for potentially important but excluded variables in the model.

Inclusion of lagged dependent variables as a regressor, though, may cause an endogeneity problem. This issue can be addressed by using the General Method of Moments (GMM) (Arellano and Bond 1991, Arellano and Bover 1995, Blundell and Bond 1998). The GMM estimator addresses issues of lagged dependent variables, unobserved fixed effects, and endogenous independent regressors, as well as the presence of heteroskedasticity and autocorrelation across and within panel members (Roodman 2009). However, the GMM method is only efficient asymptotically for "small T and large N," that is, short time span and large panel members. Thus, it is not suitable for small samples. Our dataset includes 15 countries, over a period of 10 years.

Since using the GMM is inappropriate, an alternative method is the LSDVC estimator. This method calculates bias corrected Least Square Dummy Variable (LSDV) estimators for a standard autoregressive panel data model by using the bias approximations in Bruno (2005a) which extends results by Bun and Kiviet (2003), Kiviet (1999), and Kiviet (1995) to unbalanced panels. This method is an appropriate dynamic panel data technique for small samples where GMM cannot be applied efficiently.

We rewrite the dynamic panel data model expressed in Equation (1) as follows:

$$
y_{i t}=\gamma y_{i, t-1}+X_{i t}^{\prime} \beta+\eta_{i}+\varepsilon_{i t}
$$

where $y_{i t}$ is the dependent variable, $X_{i t}$ is a set of explanatory variables, $\eta_{i}$ is an 
unobserved individual effect, and $\varepsilon_{i t}$ is an unobserved white noise disturbance.

The model can be written compactly as:

$$
y=W \delta+D \eta+\varepsilon
$$

where $W\left(=\left[y^{(-1)} \mid X\right]\right)$ is the matrix of explanatory variables and lagged dependent variables, $D$ is the NT by $N$ matrix of individual dummies, $\eta$ is the $\mathrm{N}$ by 1 vector of individual effects, $\delta$ is the $\mathrm{k}$ by 1 vector of coefficients, and $\varepsilon$ is the usual error term.

The LSDV estimator is as follows:

$$
\delta_{L D S V}=\left(W^{\prime} A W\right)^{-1} W^{\prime} A y
$$

where $A$ is the within transformation, which wipes out the individual effects.

Bun and Kiviet (2003) depicted the bias associated with the LSDV estimator as:

$$
E\left(\delta_{L D S V}-\delta\right)=c_{1}\left(T^{-1}\right)+c_{2}\left(N^{-1} T^{-1}\right)+c_{3}\left(N^{-1} T^{-2}\right)+O\left(N^{-2} T^{-2}\right)
$$

In their Monte Carlo simulations, Bun and Kiviet (2003) and Bruno (2005a) considered three possible nested approximations of the LSDV bias, which in turn are extended to the first, second, and third terms of Equation (4). ${ }^{2}$

The LSDV-corrected estimator (LSDVC) is equal to:

$$
L S D V C=\delta_{L D S V}-B_{i}, i=1,2,3
$$

In this paper, we correct for the most comprehensive and accurate one (B3 in Bun and Kiviet (2003) and Bruno (2005a) notations). We make a bias correction with the Anderson-Hsiao estimator.

${ }^{2} B_{1}=c_{1}\left(T^{-1}\right) ; B_{2}=B_{1}+c_{2}\left(N^{-l} T^{-l}\right) ; B_{3}=B_{2}+c_{3}\left(N^{-l} T^{-2}\right) ;$ 


\section{Results}

\section{A. Descriptive analysis}

Table 1 presents the variables' summary statistics. The Gini coefficient (in percentage form) varies from a 31.5 to 62 and shows a high degree of income disparity among ECOWAS countries.

Table 1. Descriptive statistics of variables

\begin{tabular}{|c|c|c|c|c|c|}
\hline Variable & Mean & $\begin{array}{l}\text { Standard } \\
\text { Deviation }\end{array}$ & Minimum & Maximum & Observations \\
\hline Gini & 42.775 & 6.913 & 31.500 & 62.000 & 150 \\
\hline $\begin{array}{l}\text { Intra-regional } \\
\text { export ratio }\end{array}$ & 0.178 & 0.165 & 0.007 & 0.635 & 150 \\
\hline $\begin{array}{l}\text { Intra-ECOWAS } \\
\text { trade share }\end{array}$ & 0.067 & 0.085 & 0.001 & 0.296 & 150 \\
\hline Remittances & 5.535 & 5.004 & 0.150 & 29.720 & 150 \\
\hline $\begin{array}{l}\text { Population } \\
\text { Growth }\end{array}$ & 2.706 & 0.639 & 1.060 & 4.515 & 150 \\
\hline Unemployment & 7.718 & 6.560 & 0.755 & 30.032 & 150 \\
\hline $\begin{array}{l}\text { Natural } \\
\text { Resources }\end{array}$ & 13.452 & 10.751 & 0.426 & 57.608 & 150 \\
\hline GDP per capita & 923.569 & 767.846 & 272.855 & 3405.78 & 150 \\
\hline$F D I$ & 6.275 & 9.517 & -0.900 & 84.946 & 150 \\
\hline $\begin{array}{l}\text { Corruption } \\
\text { Index }\end{array}$ & 2.985 & 0.707 & 2.000 & 4.500 & 131 \\
\hline $\begin{array}{l}\text { Political } \\
\text { Integration }\end{array}$ & 1.207 & 1.076 & 0.000 & 7.000 & 150 \\
\hline Inflation & 5.991 & 7.088 & -35.837 & 34.695 & 149 \\
\hline
\end{tabular}

(Note) (i) Descriptive statistics use raw data.

(ii) In percentage form, the Gini coefficient lies between $0 \%$ and $100 \%$.

(Source) authors' calculations 


\section{B. Benchmark regression}

Table 2 reports a series of regressions using the LSDVC technique. Column [1] shows the results of the basic model, with the lagged, dependent variable revealing a positive relationship. The past value of GINI accounts for the path-dependent and viscous nature of inequality. Starting from Column 2, both political and economic integration are included in the income inequality model.

The coefficient of political integration decreases slightly compared to the full model with controls. On the other hand, the coefficient of intra-regional export ratio rises slightly when additional control variables are added to the model. From columns [2] to [6], the estimates signal that, on average, a 10 percent increase in a country exports to ECOWAS (as a percentage of total country exports) will cause a 0.015 and 0.024 point increase in income inequality in ECOWAS. Therefore, the impact of economic integration measured by the intra-regional export ratio on the Gini index appears to be perverse: a significant positive effect is obtained.

Our empirical study also produces interesting results about the roles of other control variables. Results from columns [3] to [6] indicate that the coefficient related to unemployment rate is positive and significant. This denotes that a higher unemployment rate worsens income inequality. This supports recent studies on West Africa such as Anyanwu et al. (2016). A one percentage point increase in the ECOWAS unemployment rate is associated with a 0.02 percentage point increase in income inequality.

Increased FDI reduces the inequality gap in ECOWAS (columns [3], [4] and [6]). This implies that the distributional impact of FDI in ECOWAS follows the international trade pattern predicted by the Heckscher-Ohlin model and the Stolper-Samuelson theorem. Inward FDI can benefit an abundance of low-skilled workers in developing economies, such as those in ECOWAS. This, in turn, could increase the demand and wages for low-skilled labor, thereby reducing wage dispersion and income inequality in ECOWAS zone. This result is in line with the findings of Mahutga and Bandelj (2008) for eight Central and Eastern European countries; Herzer and Nunnenkamp (2013) for the 10 European countries (in the long-run); Mugeni (2015) for the 153 developing and developed countries; Sharma and Abekah (2017) for the 71 African and South American countries. 
The insignificant variables are found to be the inflation rate, remittances, the stock of natural resources, GDP per capita, population growth, and corruption levels. Even though their coefficients do not show a conventional level of significance, the inflation rate, remittances, and the stock of natural resources have a positive effect on income inequality. In contrast, population growth and corruption reveal an insignificant negative effect on the Gini coefficient.

Overall, the results show that political integration is negatively correlated with the Gini index, contrary to the findings of Beckfield (2006) which found that political integration has positive effect on income inequality for the 12 Western European countries. A plausible explanation is that ECOWAS can offer security and assurance to build supra-national institutions that will supply regional public goods. Regional political integration creates a regional social order that enables the establishment of regional markets and facilitates economic convergence, with economic entities following common rules throughout the region. (Fligstein 2001).

Higher intra-regional export ratio raises the within country income inequality. This finding supports the diversion effect of intra-regional trade on welfare in ECOWAS zone (Viner 1950). This is in light of the findings of Busemeyer and Tober (2015). As a member state becomes more economically integrated, its intra-regional trade rises. Domestic workers are likely to be replaced by foreign labor and non-labor factors (Busemeyer and Tober 2015).

For developing countries, which usually have less efficient production methods, such as those in ECOWAS, there is a risk that such trade diversion offsets trade creation and therefore negatively affects welfare (Hine 1994). Furthermore, it could be related to the low ECOWAS score obtained in the trade integration dimension in the African Regional Integration Index 2016, that is, 0.440 for ECOWAS against the 0.546 average of the eight regional communities.

De Melo and Tsikata (2014) reports that the uneven distribution of resources in African Regional Economic Communities offsets the benefits of common policies needed to tackle cross-border externalities and their costs. For Ogunkola (1998), ECOWAS is in need of a gradual approach to regional integration; rather, it must look at trade as an engine of economic growth and development of members.

Van Dijck (1992) considers two necessary conditions under which intra- 
trade welfare gains will exceed welfare losses. First, import demand should be price elastic, and price differences between member states should be large, while the price difference between member states and the world market is small. Next, if more goods are imported from non-member states before the formation of regional blocs, there would be a high tendency toward trade diversion. Based on these conditions, ECOWAS is likely to experience limited trade creation and possible negative welfare outcomes.

Table 2. LSDVC regression: Regional integration's impact on Gini

\begin{tabular}{|c|c|c|c|c|c|c|}
\hline \multirow{2}{*}{ Variable } & \multicolumn{6}{|c|}{ Least Squares Dummy Variable Corrected (LSDVC) Regression } \\
\hline & [1] & [2] & [3] & [4] & [5] & [6] \\
\hline Gini & $\begin{array}{c}0.942 * * * \\
(0.005)\end{array}$ & $\begin{array}{c}0.821 * * * \\
(0.035)\end{array}$ & $\begin{array}{c}0.802 * * * \\
(0.048)\end{array}$ & $\begin{array}{c}0.806^{* * * *} \\
(0.045)\end{array}$ & $\begin{array}{c}0.811 * * * \\
(0.078)\end{array}$ & $\begin{array}{c}0.809 * * * * \\
(0.022)\end{array}$ \\
\hline $\begin{array}{l}\text { Political } \\
\text { Integration }\end{array}$ & & $\begin{array}{c}-0.0021 * * * \\
(0.001)\end{array}$ & $\begin{array}{c}-0.0019 * * * \\
(0.001)\end{array}$ & $\begin{array}{c}-0.0018^{* * *} \\
(0.001)\end{array}$ & $\begin{array}{c}-0.0018^{* * * *} \\
(0.001)\end{array}$ & $\begin{array}{c}-0.0017 * * * \\
(0.001)\end{array}$ \\
\hline $\begin{array}{l}\text { Intra-regional } \\
\text { export }\end{array}$ & & $\begin{array}{c}0.0020 * * * \\
(0.001)\end{array}$ & $\begin{array}{c}0.0024 * * * \\
(0.001)\end{array}$ & $\begin{array}{c}0.0022^{* *} \\
(0.001)\end{array}$ & $\begin{array}{c}0.0015^{* *} \\
(0.001)\end{array}$ & $\begin{array}{c}0.0024 * * * \\
(0.001)\end{array}$ \\
\hline$F D I$ & & $\begin{array}{c}-0.0062 \\
(0.004)\end{array}$ & $\begin{array}{c}-0.0062^{*} \\
(0.004)\end{array}$ & $\begin{array}{c}-0.0063^{*} \\
(0.004)\end{array}$ & $\begin{array}{c}-0.0064 \\
(0.004)\end{array}$ & $\begin{array}{c}-0.0071 * * \\
(0.003)\end{array}$ \\
\hline $\begin{array}{l}\text { Corrup- } \\
\text { tion Index }\end{array}$ & & $\begin{array}{c}-0.0008 \\
(0.012)\end{array}$ & $\begin{array}{c}-0.0028 \\
(0.011)\end{array}$ & $\begin{array}{r}-0.0027 \\
(0.008)\end{array}$ & $\begin{array}{r}-0.0029 \\
(0.012)\end{array}$ & $\begin{array}{c}-0.0075 \\
(0.009)\end{array}$ \\
\hline Inflation & & $\begin{array}{l}0.0004 \\
(0.001)\end{array}$ & $\begin{array}{l}0.0003 \\
(0.001)\end{array}$ & $\begin{array}{l}0.0003 \\
(0.001)\end{array}$ & $\begin{array}{l}0.0004 \\
(0.001)\end{array}$ & $\begin{array}{l}0.0004 \\
(0.001)\end{array}$ \\
\hline $\begin{array}{l}\text { GDP } \\
\text { Per Capita }\end{array}$ & & $\begin{array}{c}0.023 \\
(0.045) \\
\end{array}$ & $\begin{array}{l}0.0294 \\
(0.046) \\
\end{array}$ & $\begin{array}{l}0.0259 \\
(0.049) \\
\end{array}$ & $\begin{array}{l}0.0209 \\
(0.038)\end{array}$ & $\begin{array}{l}0.0111 \\
(0.062)\end{array}$ \\
\hline $\begin{array}{l}\text { Unempl- } \\
\text { oyment }\end{array}$ & & & $\begin{array}{c}0.0220 * * * \\
(0.001)\end{array}$ & $\begin{array}{c}0.0224 * * * \\
(0.001)\end{array}$ & $\begin{array}{c}0.0245^{* * *} \\
(0.003)\end{array}$ & $\begin{array}{c}0.0255 * * * \\
(0.001)\end{array}$ \\
\hline $\begin{array}{l}\text { Population } \\
\text { Growth }\end{array}$ & & & & $\begin{array}{c}-0.0089 \\
(0.008)\end{array}$ & $\begin{array}{r}-0.0030 \\
(0.003)\end{array}$ & $\begin{array}{c}-0.0048 \\
(0.004)\end{array}$ \\
\hline $\begin{array}{l}\text { Remitt- } \\
\text { ances }\end{array}$ & & & & & $\begin{array}{l}0.0033 \\
(0.003)\end{array}$ & $\begin{array}{l}0.0013 \\
(0.004)\end{array}$ \\
\hline $\begin{array}{l}\text { Natural } \\
\text { Resources }\end{array}$ & & & & & & $\begin{array}{l}0.0103 \\
(0.010)\end{array}$ \\
\hline $\begin{array}{l}\text { Obser- } \\
\text { vations }\end{array}$ & 135 & 128 & 128 & 128 & 128 & 128 \\
\hline $\begin{array}{l}\text { Number } \\
\text { of IDs }\end{array}$ & 15 & 15 & 15 & 15 & 15 & 15 \\
\hline
\end{tabular}

(Note) bootstrapped standard errors in parentheses; *** $p<0.01, * * p<0.05, * p<0.1$.

(Source) authors' calculations 
We check the sensitivity of the coefficients use another proxy for economic integration, such as the share of total intra-regional goods trade as a percentage of total ECOWAS trade. This is one of the key indicators of trade integration used in the calculation of the African Regional Integration Index in 2016. Table 3 presents the estimated values, suggesting the same conclusion as in Table 2.

Table 3. LSDVC regression with share of total intra-regional trade

\begin{tabular}{|c|c|c|c|c|c|}
\hline \multirow{2}{*}{ Variable } & \multicolumn{5}{|c|}{ Least Squares Dummy Variable Corrected (LSDVC) Regression } \\
\hline & [1] & {$[2]$} & [3] & [4] & {$[5]$} \\
\hline Gini & $\begin{array}{l}0.826^{* * * *} \\
(0.0527)\end{array}$ & $\begin{array}{l}0.803 * * * \\
(0.0753)\end{array}$ & $\begin{array}{l}0.807 * * * \\
(0.0744)\end{array}$ & $0.809 * * *$ & $\begin{array}{l}0.808^{* * * *} \\
(0.0367)\end{array}$ \\
\hline $\begin{array}{l}\text { Political } \\
\text { Integration }\end{array}$ & $\begin{array}{c}-0.0024 * * * \\
(0.0006)\end{array}$ & $-0.0021 * * *$ & $-0.0021 * * *$ & $\begin{array}{l}-0.0021^{*} \\
(0.0011)\end{array}$ & $\begin{array}{c}-0.0020^{* * *} \\
(0.0002)\end{array}$ \\
\hline $\begin{array}{l}\text { Intra-ECOWAS } \\
\text { Trade Share }\end{array}$ & $\begin{array}{c}0.0140 * * * \\
(0.0022)\end{array}$ & $\begin{array}{c}0.0148 * * * \\
(0.0023)\end{array}$ & $0.0149 * * *$ & $\begin{array}{c}0.0145^{* * * *} \\
(0.0001)\end{array}$ & $0.0152 * * *$ \\
\hline$F D I$ & $\begin{array}{c}-0.00854^{*} \\
(0.0045)\end{array}$ & $\begin{array}{c}-0.00870^{*} \\
(0.0046)\end{array}$ & $\begin{array}{c}-0.00858^{*} \\
(0.0046)\end{array}$ & $\begin{array}{l}-0.00866 \\
(0.0059)\end{array}$ & $\begin{array}{c}-0.00953^{* *} \\
(0.0037)\end{array}$ \\
\hline $\begin{array}{l}\text { Corruption } \\
\text { Index }\end{array}$ & $\begin{array}{l}-0.002 \\
(0.0109)\end{array}$ & $\begin{array}{l}-0.0053 \\
(0.0115)\end{array}$ & $\begin{array}{l}-0.0055 \\
(0.0097)\end{array}$ & $\begin{array}{l}-0.0051 \\
(0.0146)\end{array}$ & $\begin{array}{l}-0.0090 \\
(0.0100)\end{array}$ \\
\hline Inflation & $\begin{array}{l}0.0003 \\
(0.0010)\end{array}$ & $\begin{array}{c}0.0002 \\
(0.0010)\end{array}$ & $\begin{array}{c}0.0002 \\
(0.0010)\end{array}$ & $\begin{array}{l}0.0002 \\
(0.0010)\end{array}$ & $\begin{array}{c}0.0003 \\
(0.0010)\end{array}$ \\
\hline $\begin{array}{l}\text { GDP Per } \\
\text { Capita }\end{array}$ & $\begin{array}{l}0.0207 \\
(0.0483)\end{array}$ & $\begin{array}{c}0.0277 \\
(0.0472)\end{array}$ & $\begin{array}{c}0.0294 \\
(0.0488)\end{array}$ & $\begin{array}{l}0.0273 \\
(0.0461) \\
\end{array}$ & $\begin{array}{c}0.0157 \\
(0.0698)\end{array}$ \\
\hline Unemployment & & $\begin{array}{c}0.0257 * * * \\
(0.0002)\end{array}$ & $\begin{array}{c}0.0252 * * * \\
(0.0007)\end{array}$ & $0.0262 * *$ & $\begin{array}{c}0.0276^{* * *} \\
(0.0010)\end{array}$ \\
\hline $\begin{array}{l}\text { Population } \\
\text { Growth }\end{array}$ & & & $\begin{array}{c}0.0012 \\
(0.0059)\end{array}$ & $\begin{array}{l}0.0026 \\
(0.0027)\end{array}$ & $\begin{array}{l}0.0002 \\
(0.0008)\end{array}$ \\
\hline Remittances & & & & $\begin{array}{l}0.00124 \\
(0.0036)\end{array}$ & $\begin{array}{c}-0.000813 \\
(0.0037)\end{array}$ \\
\hline $\begin{array}{l}\text { Natural } \\
\text { Resources }\end{array}$ & & & & & $\begin{array}{c}0.0112 \\
(0.0114) \\
-\end{array}$ \\
\hline Observations & 128 & 128 & 128 & 128 & 128 \\
\hline Number of IDs & 15 & 15 & 15 & 15 & 15 \\
\hline
\end{tabular}

(Note) bootstrapped standard errors in parentheses; *** $p<0.01, * * p<0.05, * p<0.1$.

(Source) authors' calculations 
The control variables show the same behavior as in the baseline estimation. Comparing results in Tables 2 and 3, we find that the coefficients for the instrumented political integration variable in Table 3 reveal a slightly higher decreasing effect on income inequality.

Overall, the results are largely consistent with our earlier findings.

\section{Conclusion}

This paper has presented comprehensive empirical evidence on the relationships between regional integration and income inequality in ECOWAS. While ECOWAS countries have made significant progress since their creation, large challenges remain for their development.

Our findings point to some key policy recommendations. Regional integration should be accompanied by structural reforms that enhance inclusiveness and reduce inequality. Since political integration reduces the inequality gap, ECOWAS needs the implementation of harmonized, regional welfare projects. We recommend the implementation of regulatory convergence in areas such as land, property rights, and taxes.

Countries in ECOWAS care for trade openness and deeper economic integration. In our findings, economic integration leads to an increase in income inequality. Thus, policies need to be designed to make economic integration profitable for the population. For example, a more effective policy is necessary to share the benefits of intra-regional trade between member states. Member states could redistribute revenue from the ECOWAS Common External Tariff. Article 48 (1) of the ECOWAS Revised Treaty (1993), which calls for compensation to be paid to a member state that has suffered a loss of import duties as a result of the intra-trade.

It is worth mentioning that ECOWAS countries have made significant efforts to reduce income inequality. However, member states should effectively follow the ECOWAS Common Agricultural Policy and the Maputo Agreement, which aim to ensure a stable income for farmers. These farmers represent $60 \%$ of the population in the zone. Also, ECOWAS countries must continue to invest in the health sector. According to the Ouagadougou Agreement, a considerable part of each country's budget is to be allocated to health. For instance, Sierra Leone allocated 18 percent of its GDP to the 
health sector in 2015. The percentage was less than seven percent for other countries in ECOWAS.

Received 15 January 2018, Revised 6 July 2018, Accepted 23 July 2018

\section{References}

Acosta, P., Fajnzylber, P., Lopez, J.H. "The impact of remittance on poverty and human capital: evidence from Latin American Household Surveys." World Bank Research Working Paper 4247 (2007). Washington DC. Accessed at http://documents.worldbank.org/curated/en/469351468046776545/What-isthe-impact-of-international-remittances-on-poverty-and-inequality-in-LatinAmerica.

Adams, J.R., Cuecuecha, A., Page, R.J. “The impact of remittance on poverty and inequality in Ghana." World Bank Research Working Paper 4732 (2008) Washington DC.

Adams, R.H. "The Effects of international remittances on poverty, inequality and development in rural Egypt." Research Report (International Food Policy Research Institute) 86 (1991) Washington DC.

Aitken, B., Harrison, A.., R.E. Lipsey. "Wages and Foreign Ownership: A Comparative Study of Mexico, Venezuela, and the United States." Journal of International Economics 40 (1996): 345-371.

Albanesi, S. "Inflation and inequality." Journal of Monetary Economics 54(4) (2007): 1088-1114.

Alderson, A., Nielsen, F. "Globalization and the Great U-Turn: Income Inequality Trends in 16 OECD Countries." American Journal of Sociology 107 
(2002): 1244-99.

Ali Hamid E., Sami Sara M. "Inequality, Economic Growth and Natural Resources Rent: Evidence From the Middle East and North Africa." Contemporary Issues in Microeconomics (2016): 50-76.

Ametoglo, M.E.S., Guo, P. "Regional economic Integration and income inequality in Latin America: the case of the Andean Community of Nations." Journal of Economics and Sustainable Development Vol. 7 No. 14 (2016): 176185.

Anyanwu, J. C. "International Remittances and Income Inequality in Africa." Review of Economic and Business Studies Vol. IV Issue 1 (2011): 117-48.

Anyanwu, J C., Erhijakpor, A. E. O., Obi, E. "Empirical Analysis of the Key Drivers of Income Inequality in West Africa." African Development Review 28(1) March (2016): 18-38.

Arellano, M., S. Bond. "Some tests of specification for panel data: Monte Carlo evidence and an application to employment equations." Review of Economic Studies 58 (1991): 277-297.

Arellano, M., Bover O. "Another Look at the Instrumental Variable Estimation of Error-components Models." Journal of Econometrics 68(1) (1995): 29-51.

Arestis, P., Eleni P. "Divergence and Peripheral Fordism in the European Union." Review of Social Economy (1995): 261-283.

Armstrong, H.W. "An Appraisal of the Evidence from Cross-Sectional Analysis of the Regional Growth Process within the European Union." in Convergence and Divergence among European Regions, edited by H.W. Armstrong and R.W. Vickerman. London: Pion Armstrong and Vickerman; and Ben-David 40-65, 2001. 
Beckfield, J. "European integration and income inequality." LIS Working Paper Series No. 447 (2006).

Beckfield, J. "Remapping inequality in Europe: The net effect of regional integration on total income inequality in the European Union." International Journal of Comparative Sociology 50(5-6) (2009): 486-509.

Blundell, R., Bond S. "Initial Conditions and Moment Restrictions in Dynamic Panel Data Models.”.Journal of Econometrics 87(1) (1998): 115-143.

Bruno, G. S. F. "Approximating the bias of the LSDV estimator for dynamic unbalanced panel data models." Economics Letters 87 (2005): 361-366.

Bulir, A. "Income Inequality: Does Inflation Matter?" IMF Working Paper (1998).

Bun, M. J. G., J. J. Kiviet. “'On the Diminishing Returns of Higher-Order Terms in Asymptotic Expansions of Bias." Economics Letters 79 (2003): 145-152.

Burley, Anne-Marie and Walter Mattli. "Europe Before the Court: A Political Theory of Legal Integration.” International Organization 47 (1993): 41-76.

Busemeyer, M., Tober, T. "European integration and the political economy of inequality.” European Union Politics 16(4) (2015): 536-557.

Chenery Hollis. "Redistribution with Growth: Policies to Improve Income Distribution in Developing Countries in the Context of Economic Growth." Population and Development Review Vol. 2 (1976): 284-285.

Claus, I., Martinez-Vazquez, J., Vulovic, V., "Government Fiscal Policies and Redistribution in Asian Countries." ADB Economics Working Paper Series No. 310. (2012) Manila: Asian Development Bank.

De Melo, J., Tsikata Y., "Regional integration in Africa Challenges and 
prospects.” WIDER Working Paper 2014/037 (2014).

De Melo, J., Gourdon, J.,Maystre, N. "Openness, Inequality and Poverty: Endowments Matter.” CEPR Discussion Papers N. 5738, Centre for Economic Policy Research, London. (2006).

Deininger, K., L. Squire. "Economic Growth and Income Inequality: Reexamining the Links." Finance and Development 34 (1997): 38-41.

Dijck, P. van "Preferential Trade among Developing Countries." New Delhi: Sage Publications (1992).

ECOWAS. "Revised Treaty of the Economic Community of West African States (ECOWAS)." Accessed at http://www.ecowas.int/wp-content/uploads/ 2015/01/Revised-treaty.pdf. (1993).

Ezaki, M., Nguyen, T. D. "Regional Economic Integration and Its Impacts on Growth, Income Distribution and Poverty in East Asia: A CGE Analysis.” Graduate School of International Development, Nagoya University Discussion Paper No.167. (2008).

Feenstra, R.C., G.H. Hanson. "Foreign Direct Investment and Relative Wages: Evidence from Mexico's Maquiladoras." Journal of International Economics, 42, (1997): 371-393.

Fishlow, A. "Inequality, Poverty and Growth, Where Do We Stand?" In OPS Document Reproduction Series 65. World Bank (1995).

Fligstein, N. "The Architecture of Markets." Princeton: Princeton University Press (2001).

Fligstein, N., Stone Sweet, A. "Constructing Polities and Markets: An Institutionalist Account of European Integration." American Journal of Sociology 107 (2002): 1206-43. 
Frankel, J.A., "Regional Trading Blocs in the World Economic System." Washington, D.C.: Institute for International Economics, (1997).

Fujita, M., Krugman, P., Venables A. J. "The spatial economy: Cities, regions and international trade." The MIT Press (1999).

Gubert, F., Lassourd, T., Mesplé-Somps. S., "Do remittances affect poverty and inequality?: Evidence from Mali.” (2009). accessed November 1, 2017. http:// gdri.dreem.free.fr/wp-content/gubert_lassourd_mesple-somps_paper.pdf.

Gupta, S., Davoodi, H., Alonso-Terme, R., "Does Corruption Affect Income Inequality and Poverty?" IMF Working Paper No. WP/98/76. (1998).

Gyimah-Brempong, K., "Corruption, Economic Growth and Income Inequality in Africa." Economics of Governance (3) (2002): 183-209.

Hanson, G.H., "What Has Happened to Wages in Mexico since NAFTA? Implications for Hemispheric Free Trade." National Bureau of Economic Research, NBER Working Paper 9563. Cambridge, MA, (2003).

Hérault, N., "Trade Liberalisation, Poverty and Inequality in South Africa: A CGE-Microsimulation Analysis." Melbourne Institute Working Paper Series wp2005n17, Melbourne Institute of Applied Economic and Social Research, The University of Melbourne. (2005).

Herzer, D., Nunnenkamp, P "Inward and outward FDI and income inequality: evidence from Europe." Review of World Economics 149 (2013): 395-422. doi: 10.1007/s10290-013-0148-3.

Hyungsun, C.C., Ramirez D.M., "Foreign direct investment and inequality in Southeast Asia: A panel unit root and panel cointegration analysis, 19902013.” Atlantic Economic Journal (44) (2017): 411-24.

Johnson, H.G., "A note on welfare-increasing trade diversion." The Canadian 
Journal of Economics 8 (1) (1975).

Kiviet, J.F., "On the Rigour of Some Misspecification Tests For Modelling Dynamic Relationships.” Review of Economic Studies LIII (1986): 241-261.

Kiviet, J.F., "On Bias, Inconsistency, and Efficiency of various Estimators in Dynamic Panel data Models.” Journal of Econometrics 68 (1995): 53-78.

Kuznets, S., "Economic Growth and Income Inequality." American Economic Review 45 (March 1955): 1-28.

Kweka, J., Mboya, F., "Regional Integration and Poverty: The case of Tanzania.” Report. Economic and Social Reseearch Foundation (2004).

Leonardi, R., "Convergence, Cohesion, and Integration in the European Union.” New York: St. Martin's Press (1995).

Lopez, H., "Macroeconomics and Inequality." Washington DC: The World Bank (2004).

Mahutga, M.C., Bandelj, N., "Foreign investment and income inequality: The natural experiment of Central and Eastern Europe." International Journal of Comparative Sociology 49 (2008): 429-454. doi: 10.1177/0020715208097788.

Mansfield, E., Solingen, E., "Regionalism.” Annual Review of Political Science Vol. 13 (2010): 145-163. Accessed at http://dx.doi.org/10.1146/annurev. polisci.13.050807.161356.

Martin, P., "Public policies and economic geography." CEPR Discussion Paper Series (2002).

Monnin, P., "Inflation and Income Inequality in Developed Economies." CEP Working Paper 2014/1 (May 2014).

Mugeni, S., "Foreign Investment, Democracy and Income Inequality: Empirical 
Evidence." Master's Thesis, Department of Economics, University of Ottawa. (2015).

Ogunkola E.O., "An empirical evaluation of trade potential in the economic community of West African States." AERC Research Paper 84 African Economic Research Consortium, Nairobi November (1998).

Osakwe P.N., "Transformative Regionalism, Trade and the Challenge of Poverty Reduction in Africa." Trade And Poverty Paper Series No. 1, (2015).

Puga, D., "The rise and fall of regional inequalities." European Economic Review 43 (1999): 303-334.

Ravallion, M., "Growth and Poverty: Evidence for Developing Countries in the 1980s." Economics Letters 48(3) (1995): 411-417.

Reuveny, R., Lee, Q., "Economic Openness, Democracy and Income Inequality: An Empirical Analysis.” Comparative Political Studies (2003): 36, 575.

Roodman, D., "A Note on the Theme of Too Many Instruments." Oxford Bulletin of Economics and Statistics 71, 1 (2009): 135-158.

Sharma, B., Abekah J., "Foreign direct investment, foreign aid and incomes inequality: Empirical insights from African and South American countries." Transnational Corporations Review 9:1 (2017): 1-7, DOI: 10.1080/19186444.2017.1290912.

Slaughter, M., "Trade Liberalization and Per Capita Income Convergence: A Difference-in-Differences Analysi." Journal of International Economics 55 (2001): 203-228.

Tebaldi, E., Mohan, R., "Institutions and poverty." Journal of Development Studies. Taylor and Francis Journals Vol. 46 No. 6 (2010): 1047-1066. 
Torvik, R., "Natural resources, rent seeking and welfare." Journal of Development Economics (2002).

UNCTADstat., "United Nations Conference on Trade and Development Statistics Merchandise Trade Matrix." Accessed at http://unctadstat.unctad. org/EN/. (2017).

UNDP., "UNDP Human Development Reports- HDI index." Accessed at http://hdr.undp.org/en/composite/trends. (2016).

Viner, J., “The Customs Union Issue.” New York: Carnegie Endowment for International Peace (1950).

Western, B., "Between Class and Market: Postwar Unionization in Capitalist Democracies.” Princeton, NJ: Princeton University Press (1997). 
